\title{
The Prophets Communication with Non-Human Creatures in the Holy Qur'an and Its Influence on the Calling to Islam
}

\author{
Dr. Majed Rajab Al - Abid Sukkar* \\ Assistant Professor of Tafseer (Interpretation) and Sciences of the Qur'an, Al - Aqsa University - Palestine \\ *Corresponding Author: Dr. Majed Rajab Al - Abid Sukkar, Assistant Professor of Tafseer \\ (Interpretation) and Sciences of the Qur'an, Al - Aqsa University - Palestine
}

\begin{abstract}
The study talks about the definition of communication and the relationship between it and contact, and then shows how the prophets communicate with other creatures, for example; the Prophet Muhammad peace be upon him with the jinn, trees and stones, and how the prophet David communicated with birds, And Solaiman with the jinn, with the ant and with the hoopoe, And it the researcher concluded a number of results, which have an important role in the history of calling to Islam, and the creativity in making dialogues with others.
\end{abstract}

\section{INTRODUCTION}

Praises be to Allah, The lord of the Worlds, and all prayers and peace be upon who has been sent as mercy to the worlds, and prayers and peace be upon His family and companions, and those who followed him well until the Day of Judgment,

Having said that, Islam is a universal and wide message, and it expands to the whole universe, and to all those in it, people, plants, animals, mountains and seas, because of its fair, easy and wise rules, Islam is developing people because of its legislation from individual to collective, from being closed to the permissible openness, from intolerance to tolerance, from complexity and difficulty to facilitation, from extremism to moderation, Islam raised human thought and mission in life from narrow nationalism to internationalism, from regional goals to universality, from fear to courage, from selfishness to care of interests of others. Rather, Islam by easy and appropriate laws for all time exceeded the idea of communication between Muslims and others - individual or group, human or non-human, from limited communication to the intellectual and objective and broad and appropriate. Islam is the transfer of man from theoretical integration with others to true integration, from the negative treatment that is not useful to the positive coexistence.

In this sense, I have chosen to write in a new type of communication, namely communication with non-human beings - especially the communication of prophets and messengers - and its impact on the calling to Islam.

\subsection{The Importance of this Research and the Reasons for Choosing the Subject}

- The Koran is full of educational lessons that build the journey of preachers to Islam.

- Communicating with non-humans is a different pattern from communicating with humans.

- What happened to people and their understanding of dealing with the jinn.

- New research will be added to the Islamic library.

2. ReSEARCh Methodology

- The researcher used the descriptive analytical method in the conclusion of educational lessons.

- The researcher quoted the sayings of the scholars of interpretation about the verses related to the subject and attributed them to their sources.

- The research was limited to the correct hadiths and was attributed to its sources.

\subsection{Research Plan}

The research consists of: Introduction, four chapters, and a conclusion, as follows: 
The introduction includes the importance of the research, the reasons for its selection, the methodology of the study and its plan.

Chapter 1: The concept of communication and its relation with contact.

Part 1: Communication linguistically and terminologically.

Part 2: The relationship between communication and contact.

Chapter 2: Communication with the intangible world.

Chapter 3: Communication with the physical world.

Part 1: Contact with ants.

Part 2: Contact with the Hoopoe.

Chapter 4: Communication with Trees, Stones and Mountains.

Part 1: Contact with trees and stones.

Part 2: Contact with Mountains.

\section{CHAPTER 1: The CONCEPT OF COMMUNiCATION AND ITS RELATION WITH CONTACT}

The interaction between people with each other is very important; information, feelings and ideas move through different communication channels, including what is familiar to people, or not, and this interaction is called "communication" or "contact', and to understand the concept of communication and its relationship with contact we should understand and define the communication.

\subsection{Part1. Communication Linguistically and Terminologically}

\subsubsection{First: Communication linguistically}

Refer to the Arabic root (WA SA LA)It indicates the attachment of something to something until it accompanies it. ${ }^{(1)}$ The connection is the opposite of abandonment ${ }^{(2)}$ for example: he visits his relatives, and the thing contacts the other thing, and he continued to fast. ${ }^{(3)}$ The connection is the opposite of abandonment, and alwasl in Arabic is the message you send to your friend ${ }^{(4)}$

In the hadeeth of Asmabint Abu Bakr (cursed the woman who fixes hair extensions (to another) and the woman who has them fixed for her) ${ }^{(5)}$ and alwasila is A woman who ties the hair to another hair, and almustawsila is The woman who asked that for her hair. ${ }^{(6)}$

Based on these linguistic meanings, it is clear that the purpose of communication in language is conjugation, communication, connection, collection, reporting or saying and informing, as there is a similarity in significance and meaning.

There are other dictionaries and sources that do not have the space to determine the meaning of the word (communication) and the word (contact). Accordingly, it can be said that the communication is the opposite of fighting, the quarrels and the abandonment. In other words, All forms of interaction and integration out of good morality, kindness, care and care based on the meaning of the word "Kinship" which means in general in the scholars and in language and in tafseer, jurisprudence and in essential rules, so, close relatives of the descent, and sympathy, and compassion, and care for their condition and They did bad things or if they abused.

These meanings refer to the meaning of interconnection, which is the same root fed by the mode of interaction on which the concept of communication is based, a formula that calls at least two parties to get attracted or tied.

\subsubsection{Second: Communication Terminologically}

Dr. Essam Suleiman Al-Mousa has defined it in two definitions:

\footnotetext{
${ }^{(1)}$ Ibn Fares, Dictionary of Language Standards, C6, p. 115.

${ }^{(2)}$ IbnManzoor, the tongue of the Arabs, c 11, p. 726.

${ }^{(3)}$ Azhari, language refinement, C 12, p. 165.

${ }^{(4)}$ See al-Zubaidi: The crown of the bride, c 31, p.

${ }^{(5)}$ Saheeh al-Bukhari, the book of dress, the door of the link in poetry, c 7, p. 165.

${ }^{(6)}$ See Al-Razi, Mukhtar al-Sahah, p. 340.
} 
- definition means the continuation of the strong relationship between the pillars of the relationship ${ }^{(7)}$

- Definition means openness to the other in a continuous relationship does not stop until it comes back again ${ }^{(8)}$

Dr. Omar Nasrallah defined him as: "a relationship between at least two individuals each of which is an active independent entity"(9)

What I am comfortable with is that communication means building a relationship between two individuals, or between two communities, which is mutually beneficial.

\subsection{Part 2: The Relationship between Communication and Contact}

"Some Arab researchers see it as more appropriate to use a word of communication than the word contact for linguistic and academic reasons; the verb refers to a partnership between two pillars (members or things), and the desire to establish a relationship with another person is often emotional. The word "contact" means that something has desired. This indicates a desire of one of the parties to establish a relationship with the other, and that the other may feel or want interactively with that desire and may reject it, so the use of the expression reflects the reality of the situation. ${ }^{(10)}$

They differentiate between them, saying that communication is a term used to refer to the process of transmitting information in humans or inanimate objects alike, Because of the qualitative differences between man on the one hand and other creatures on the other, it would have been better to dedicate a term to describe this process in human which is communication. ${ }^{(11)}$

In my opinion, the distinction must be made between communication and contact as they have a general and special meaning. The former is more general and comprehensive than other. Communication is a process between two parties, each of which has its own feelings and desire, Contact includes what has feelings, and what has no feelings, for example, machines.

\section{Chapter 2: COMMUNiCATION WiTh THE INTANGIBLE WorLd}

From communication in the intangible world; communication with the world of jinn, faith about the Jinn is obligatory, and every Muslim who has faith must believe in their presence because there are texts in the Quran and Sunnah about it, Therefore it is necessary to believe in the life of these creatures and their relations and communication with creatures of a different kind.

Muslims and non-Muslims agree on the existence of these creatures, "when the subject of the existence of the jinn is clear in the prophets peace be upon them are known by all people, and none of the Muslims can deny it; it is important that all Muslims believe in the existence of jinn, and most unbelievers as the people of the book, and unbelievers from the Arabs and others" ${ }^{\text {(12) }}$

There are two kinds of communication with the jinn, a type in which the genie continues to connect with the human being by making him insane, which called the epilepsy, Allah says in surah albaqara:

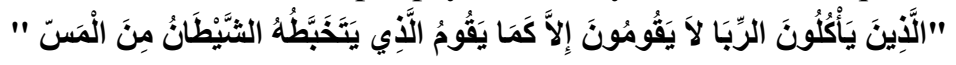

Those who devour usury will not stand except as stand one whom the Evil one by his touch Hath driven to madness. \{Albaqara 275\}

Imam altabari may God have mercy on him he said: they will not stand except as stand one whom the Evil one by his touch Hath driven to madness, it means: it causes madness on him, and it causes epilepsy on him. ${ }^{(13)}$

The devil may touch the human, as stated in the Quran that the devil makes the person crazy and shows the bad habits, as all of them say the same about himself, unanimously. ${ }^{(14)}$

\footnotetext{
${ }^{(7)}$ Essam Al-Mousa, The Introduction to Communication, p. 22.

${ }^{(8)}$ The same resource , P. 25.

${ }^{(9)}$ Mahmoud Ismail, Principles of Communication Science, p. 30.

${ }^{(10)}$ Essam Al-Mousa, Introduction to Communication, p. 48.

${ }^{(11)}$ Mahmoud Ismail, Principles of Communication Science, p. 39.

${ }^{(12)}$ Shibli, Coral Corolla, p. 21.

${ }^{(13)}$ Al-Tabari, Al-Bayan Mosque, A 5, p.
} 
Allah says in surah Annisaa:

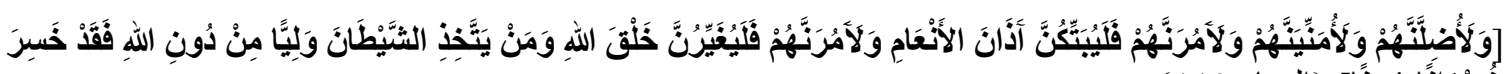

خُسْرَانًَا مُبِينًا

"I will mislead them, and I will create in them false desires; I will order them to slit the ears of cattle, and to deface the (fair) nature created by Allah." Whoever, forsaking Allah, takes satan for a friend, hath of a surety suffered a loss that is manifest. \{An_nisaa 119\}

It is an example of deceit, and a proof of evil communication, Because the sinner responds to the call of Satan.

Even in another verse Satan has promised people to prevent them from walking on the straight path of religion, denying faith, decorating infidelity and disobedience to people, Satan breaking the covenants,

Allah says in surah Al_A'raf:

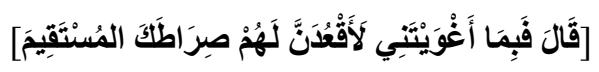

He said: Now, because Thou hast sent me astray, verily I shall lurk in ambush for them on Thy Right Path. \{Al_Ala'raf16\}

Satan and his soldiers were gathered from the demons on the road that leads to God, and with them the cleverness, the adornment and the like. We have to learn from the religion of God what becomes a weapon to fight these devils. Do not hide or grieve if we accept God, and trust us, and listened to his argument and evidence, Allah says:

$$
\text { [إنَّ كَيْدَ اللثَّيَّطَانِ كَانَ ضَعِيفًا }
$$

Indeed, satan's guile is always weak. $\{\text { An_nisa' } 76\}^{(15)}$

And the second type begins with human communication with the jinn, which recognizes the absolute ability of God alone; the easiest communication in this universe, and the weakest creatures, and the greatest Creator has mocked the creatures - different races - ways of communication sometimes, as the researcher finds_ to reach the message, Honesty, and the establishment of the argument, without distinction between creatures, and to uphold the religion of God, and to achieve the goal of creating all creatures, Allah says in Surah Adh-Dhariyat:

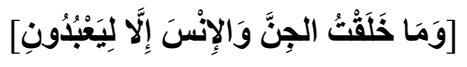

"I have only created Jinns and men, that they may worship Me" \{Adh-Dhariyat 56\}

Abu Haneefah - may God have mercy on him - said: To worship me alone ${ }^{(16)}$, if they differed in the origin of matter and creation, they agreed in the purpose of creation and creation, I think that the contact with the jinn is one of two types, either positive and beneficial, or negative and destructive.

And an example of the type of useful communication; continue to the full sincere, and the caller to the Quran _message, the Messenger for mankind section and all creatures. In more than one incident, the Prophet (peace and blessings of Allaah be upon him) urged people to worship Allah and to believe in the Holy Qur'an.

Allah says in Surah Al-Ahqaf:

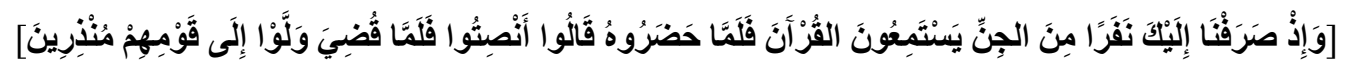

And when We inclined toward thee (Muhammad) certain of the jinn, who wished to hear the Qur'an and, when they were in its presence, said: Give ear! and, when it was finished, turned back to their people, warning. $\{$ Al-Ahqaf 29\}, Muqatil (may Allaah have mercy on him) said: The verse means: We sent to you, Muhammad, a group of jinn to hear the Qur'aan. They are people of the great jinn and their masters from the region of Yemen from a village called Nisibin. ${ }^{(17)}$

\footnotetext{
${ }^{(14)}$ Al-Qurtubi, chapter 5, p.

${ }^{(15)}$ Alousi, chapter of speech, p. 10.

${ }^{(16)}$ Abu Hanifa, the greatest jurisprudence, p. 165.

${ }^{(17)}$ Muqatil interpretation, C4, p. 27.
} 
This group of jinn when they heard the verses of the Creator Almighty, and understood the verses and when the Prophet ended the reciting, the group of jinn went to their parents and friends to teach them what they heard from the Quran, they warned them of the torment of God and of his wrath, and they became believers. ${ }^{(18)}$ They have learned the true path after listening to the Holy Quran with the voice of the best creatures. How can this not happen? God has placed the light of faith in their hearts, and they have realized the truth of faith and raised the banner of Islam in the world of jinn. Thus began other creatures enter into Islam, and they are interested in inviting creatures to Islam" ${ }^{(19)}$

The Messenger of Allah said "When the caller from the jinn came to me, I went to teach them how to recite Quran, and I saw their Signs and the Signs of their fire" ${ }^{\prime(20)}$

The negative communication with the jinn is that the person is asking the jinn, or worshiping him, and the relationship between them may develop, and the communication between them causes destruction. The person orders the person to obey them and teach them the magic to achieve their goals. This is disbelief, or ask sorcerers and believe them, this unbelief, and the way to save from the jinn to read a verse of Alkursi. ${ }^{(21)}$

Therefore, the people's relationship with the jinn is limited, and their interaction with the jinn must be within the bounds of Islam, away from misguidance, so that the will goals are achieved. In contrast, not every epilepsy is caused by elves. And they may not be aware of them, and may be treated by Quran and sunnah, Koran and sunnah have an impact on healing of all the diseases. ${ }^{(22)}$

\section{Chapter 3: Communication With the Physical World}

\subsection{Part 1: Contact with Ants}

The word "ant" once heard by the ears, comes to mind, the story of the ant with the Prophet solaiman, peace be upon him, showing the strangest types of communication, small insect has little science, and lives on the nature, keen to survive, and prepare to sacrifice itself For her sisters of ants to save herself and save her sisters, this revelation inspired by God to his prophet Solomon,

This is how the communication of the Beneficent was achieved. This communication began with this situation with King Solaiman, who had many types of soldiers. When Suleiman arrived at a valley from the valleys, he got that communication. Allah said: "when they came to the ants valley." Qatada (may Allaah have mercy on him) said: "it is in al-Sham"(23) and it is in Palestine, specifically in the city of Askalan. ${ }^{(24)}$

This call and this sense of communication with the Prophet did not meet tyranny or arrogance from the Prophet of God Solaiman, but the smile and humility, Solomon was not despotic, He was a prophet and a king, looking at the creatures of God, appreciating her opinion, hearing her words, and discussing them to reach the truth.

When he approached the valley of ants, an ant said to her brothers: Enter your dwellings, so that Solomon and his soldiers will not kill you, and they will not feel their grotesque. So Solomon heard the speech of the ant, he did not get angry, did not disobey, and did not change his command. But encouraged the work, and thanked God who taught him the logic of ants. ${ }^{(25)}$

The ant said that a prophet from the Prophets came, he responded, and smiled for her good communication with her family, so she remembered to recite, and he would worship in his recitation until the Day of Judgment. The ant, with the honor to initiate her own call sisters and communicate with them without authorization. And say: so they'll not destroy you "Solomon and his soldiers", I mean, Solomon does not destroy you and his soldiers while they do not feel your destruction. ${ }^{(26)} \mathrm{Or}$

\footnotetext{
${ }^{(18)}$ Izz al-Din ibnAbd al-Salam, interpretation of the Koran, C 3, p. 190.

(19) Ahmed Glouche, Biography of the Prophet, p.

${ }^{(20)}$ Mohammed bin Abdul Karim, graduation speeches raised, p. 893.

${ }^{(21)}$ Ibn 'Uthaymeen, the useful saying, c 1, p. 547.

${ }^{(22)}$ Omar Al-Ashqar, Islamic Creed, C3, p. 198.

${ }^{(23)}$ IbnAbiZamanin, interpretation of the Koran Aziz, C 3, p. 296.

${ }^{(24)}$ Muhammad Shurrab, the most famous monuments, p. 192.

${ }^{(25)}$ See: Ahmed Glouche, Invitation of the Apostles, p. 431.

${ }^{(26)}$ The interpretation of a fighter, c 3 p. 299.
} 
that the meaning is that the ants do not feel that Solomon peace be upon them understand their words ${ }^{(27)}$, The ant meant to limit its useful communication to its sisters and respond to this communication and benefit from it, but it arrived to the Prophet peace be upon him, "Solomon heard her from three miles, until he heard when she said:" They do not feel" ${ }^{(28)}$ In appreciation of Suleiman for the good intentions of the ant, when she said: [They do not feel], and he responded to this beautiful communication, with the smile, he said: [he became smile from her speech] Mujahid (may Allah have mercy on him) said: "He laughed at her (peace and blessings from Allah be upon him) for his justice in his property. If he felt you, he would not destroy you."(29)

And the beauty in the continuation of the ant with Solomon peace be upon him, that Solomon remembered because of the ant many blessings, and he began to ask and thank Allah. Allah said in surah An_naml:

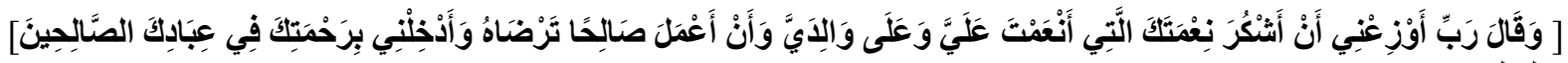

Which means :and said: My Lord, arouse me to be thankful for Thy favor wherewith Thou hast favored me and my parents, and to do good that shall be pleasing unto Thee, and include me in (the number of) Thy righteous staves.

When a man praises his Lord, this is not in the hand of man, but with the help of God. The duty of the slave is to pray to Allah to help him to thank Him, but to thank God for his knowledge of His thanks. To walk only by his command, not to eat and sleep and think only by his command, and the best thanks is the thanks of the slaves to their master. ${ }^{(30)}$

And I say: Praise be to God, how much to communicate with this ant of the benefits; like to help creatures survive, and remembering blessings, and the security of the community, and this is the useful communication with non-humans.

\subsection{Part 2: Contact with the Hoopoe}

ALLAH says in surah An_naml $\{20-31\}$ :

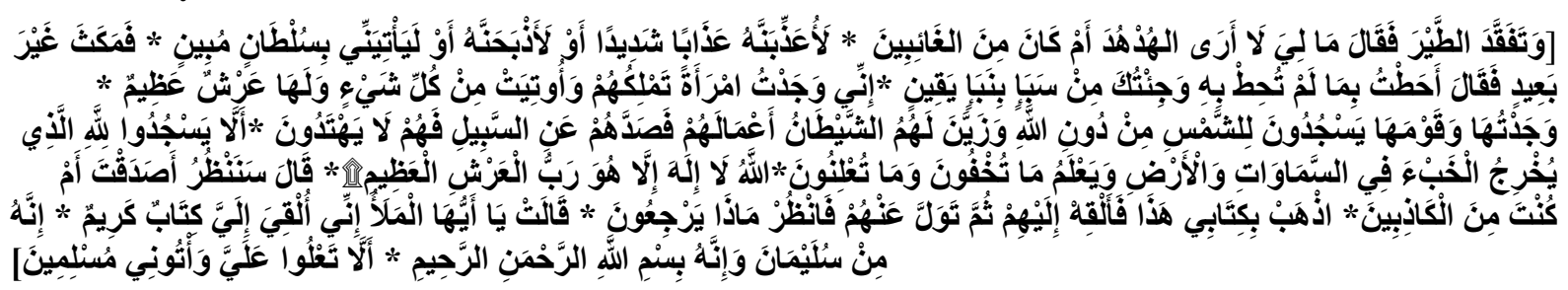

"And he took a muster of the Birds; and he said: "Why is it I see not the Hoopoe? Or is he among the absentees?, "I will certainly punish him with a severe penalty, or execute him, unless he bring me a clear reason (for absence).", But the Hoopoe tarried not far: he (came up and) said: "I have compassed (territory) which thou hast not compassed, and I have come to thee from Saba with tidings true, "I found (there) a woman ruling over them and provided with every requisite; and she has a magnificent throne, "I found her and her people worshipping the sun besides Allah: Satan has made their deeds seem pleasing in their eyes, and has kept them away from the Path,- so they receive no guidance, "(Kept them away from the Path), that they should not worship Allah, Who brings to light what is hidden in the heavens and the earth, and knows what ye hide and what ye reveal, "Allah!- there is no god but He!- Lord of the Throne Supreme!", (Solomon) said: "Soon shall we see whether thou hast told the truth or lied!, "Go thou, with this letter of mine, and deliver it to them: then draw back from them, and (wait to) see what answer they return", (The queen) said: "Ye chiefs! here is delivered to me - a letter worthy of respect, "It is from Solomon, and is (as follows): 'In the name of Allah, Most Gracious, Most Merciful, 'Be ye not arrogant against me, but come to me in submission (to the true Religion)"

\footnotetext{
${ }^{(27)}$ The interpretation of Yahyaibn Salam, c 2, p. 537.

${ }^{(28)}$ The interpretation of mujahid, c. 3, p. 299.

${ }^{(29)}$ The interpretation of mujahid, c. 3, p. 299.

${ }^{(30)}$ Al-Istari interpretation, $\mathrm{p}$.
} 
"The verses speak about a story of one of the creatures, the hoopoe bird who felt sad because of the unbelief of those who worship the sun, and did not use their minds, which God gave them to think. The hoopoe started calling to Islam as much as possible, And the Prophet of Allah, solaiman peace be upon him, is working hard for Islam, and Belqis converts to Islam". ${ }^{(31)}$

A story that needs pause to realize that many of those who have health and wellness, science and money, have limited view about the right of Allah, How can a small creature, a simple one, spread the truth which unfortunately many Muslims have been left behind them. It is educational scientific stops I will focus in the story of the Hoopoe.

The Hoopoe has addressed his King Solomon with words of great beauty. He decorated his speech with coordination and order, and boldness deserves to stand to enjoy the speech that many Muslims cannot do.

Solaiman peace be upon him was the king; He does not leave his kingdom without control and following-up.

He even checked the bird-Flocks, even if they were birds, he wanted to see if all of them had attended all of them and were present in his place or not, and he was checking all the workers, King Solomon went out in his great procession, He went to inspect the bird, but he could not find the hoopoe, And we understand from this that it's a specific hoopoe has advantages, and not like any hoopoe.

And this indicates the status of firmness and the strength of focus and accuracy, when Solomon peace be upon him;

He did not forget the absence of a soldier from this huge insect of jinn, people and birds, which gathers them all so as not to disperse.

When Suleiman learned that the Hoopoe had been absent without permission, he threatened him.

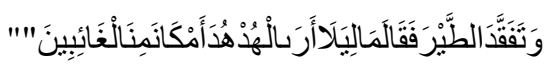

"And he took a muster of the Birds; and he said: "Why is it I see not the Hoopoe? Or is he among the absentees?"

And this threat shows the strength of Solomon peace be upon him when he discovers any negligence in his kingdom, even if the default issued by the beautiful hoopoe of the most beautiful birds, but the discipline characteristic of religiosity and commitment. ${ }^{(32)}$ No one would say how this prophet the king can torture a small bird or kill him simply because he has missed his place without permission, but Solomon (peace be upon him) is not an unjust king in the land he is a prophet, He did not hear at that moment the excuse of the absent bird, It should not be before hearing the excuse from him, And so the Prophet just Solomon said :

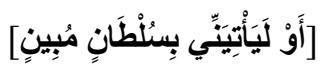

It means a strong clear excuse to not torture him. ${ }^{(33)}$

The Hoopoe returned to Solomon and wasn't late; because he knows that he missed him, and he went without his permission; so, When the Hoopoe reached Sulaiman, he came quickly, because the Hoopoe saw him angry and he knows he could punish him, Therefore Hoopoe spoke before Solomon, Hoopoe said to Suleiman:

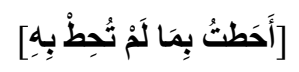

It Means "I knew what you did not know", This was said by the Hoopoe to Solomon, who is the king of the whole world, and God gave him everything. So Solomon was astonished by what the Hoopoe said, and he was eager to hear what he knew. ${ }^{(34)}$

Hoopoe says to him I know what you do not know, Prophet Solomon, who has the soldiers and great power, I know what you have not learned; I have taken note of what you have not taught him, What is

${ }^{(31)}$ MuhannaNajm, The Hoophic Rules, p. 10.

${ }^{(32)}$ Qutb, Shadows, c 5, p.

${ }^{(33)}$ Qutb, c 5, p.

${ }^{(34)}$ Al-Sha'rawi, Al-Khawat, c 17, p. 10769. 
this boldness, The little bird and the torment waiting for you, How did you get the courage to start your speech with such boldness?

This creature is one of those ruled by Solomon, a bird that has this boldness, how about the rest of the soldiers?

He told him this powerful introduction, and then followed it with documentation, as in the verse:

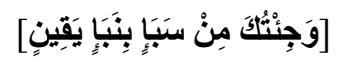

And I have come to thee from Saba with tidings true. It means that the news I carry certainly does not a doubt, In this way he documents his story and his news before he speaks it, This is a reference to what some people lack in understanding the news, as they are ignorant or neglect to document the news and narrations before starting to speak, But the hoopoe knows that he is talking with a prophet who does not accept the news without documentation or proof.

Then the hoopoe began to explain his excuse and the reason for this serious introduction and strong started.

The Holy Quran mentioned the details of the story of the Queen of Yemen (Balqis), because there are many benefits and lessons that increase the faith, so the Hoopoe said:

First: He found the property there for a woman.

Secondly: she is rich, and the has equipments for a war, weapons and fighting machines etc.

Third: that she has a great throne, she is sitting on it, this is what related to this life, Allahmentioned what the hoopoe said:

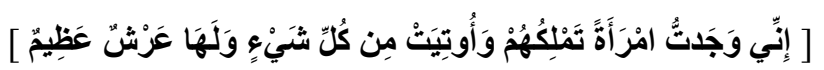

"I found (there) a woman ruling over them and provided with every requisite; and she has a magnificent throne". ${ }^{(35)}$

Suleiman threatened the Flying Crown Owner, despite its light weight, weak legs, faster in the attempt to reform, and the best means to the fullest:

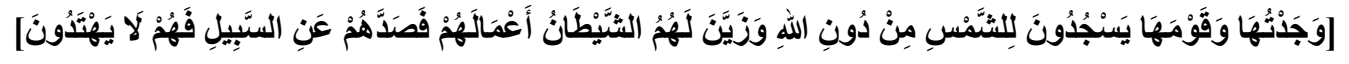

"I found her and her people worshipping the sun besides Allah: Satan has made their deeds seem pleasing in their eyes, and has kept them away from the Path,- so they receive no guidance"

His saying this includes two types of reform: heart and tongue.

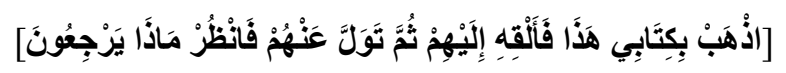

"Go thou, with this letter of mine, and deliver it to them: then draw back from them and (wait to) see what answer they return"

And here comes the reform by force, This communication is denying evil, As in the hadeeth of Abu Sa'eed al-Khudri, may God be pleased with him, he reported that the Messenger of Allah_Peace be upon him_said: "Whoever amongst you sees an evil, he must change it with his hand; if he is unable to do so, then with his tongue; and if he is unable to do so, then with his heart; and that is the weakest form of Faith". ${ }^{(36)}$

In this position, the content of the message has not been announced, so the queen opens the letter. The surprise is there, "Bilqis describes the book that it's generous, this description may be a danger to her mind of its form, or of its contents, which she announced to the public when she said:

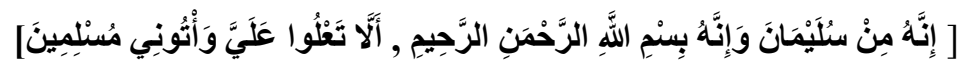

Which means: "It is from Solomon, and is (as follows): 'In the name of Allah, Most Gracious, Most Merciful, 'be ye not arrogant against me, but come to me in submission (to the true Religion).

${ }^{(35)}$ Abdul Aziz Al-Salman, Al-Anwar Al-Satarat, 3, p. 136.

${ }^{(36)}$ Muslim, book of faith, the door of the statement 1-69 
And it wasn't at that moment a believer, but Solomon was very famous, and because of the language of the message and strength, So I mentioned the description we knew, The message is simple and power; the message is read in the name of God the Merciful, And one thing is required: (Do not be arrogant against me, but come to me in submission. ${ }^{(37)}$

It is good for us to conclude some of the benefits of the Prophet peace be upon him with the hoopoe.

\subsection{Some Benefits from the Story of the Hoopoe with Solomon(38)}

- The Hoopoe was calling for goodness, worshiping God alone and prostrating for him. ${ }^{(39)}$

- The first thing to mention here is that the leader should chick his people, inspect their situations, and take care of their affairs, otherwise he was not named responsible, Ibn 'Umar (May Allah be pleased with them) reported: I heard Messenger of Allah (Peace be upon him) saying, "All of you are guardians and are responsible for your wards. The ruler is a guardian and responsible for his subjects; the man is a guardian and responsible for his family; the woman is a guardian and is responsible for her husband's house and his offspring; and so all of you are guardians and are responsible for your wards." ${ }^{(40)}$

And this is what the Prophet Solomon himself continued:

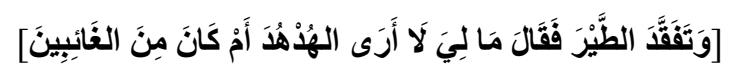

And he took a muster of the Birds; and he said: "Why is it I see not the Hoopoe? Or is he among the absentees?

A sense of responsibility, and to inquire about the reason for absence without permission was accompanied by firmness:

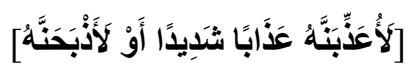

"I will certainly punish him with a severe penalty, or execute him"

And because the hoopoe is famous as inspector the places of water, the justice of the king which is required, came:

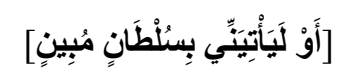

Unless he bring me a clear reason (for absence)

- It is the duties of the governors to inspect the affairs of the people, and to inspect the workers and others themselves, or to whom they are entrusted with it. ${ }^{(41)}$

- Absence without permission of disobedience requires punishment. ${ }^{(42)}$

- The accuracy of the ruler's speech and his briefings about the people, and the shortening of speech, and showing anger if there is a defect and threat of punishment so that the soldiers and workers hear them. ${ }^{(4)}$

- The act of the Hoopoe and his words shows the severity of his loyalty to the system of the state and his keenness to serve the regime and fight against its enemies, and thus be the model state that each person to serve them. ${ }^{(44)}$

- To not underestimate the rights of other creatures of God Almighty, and not be impressed with yourself:

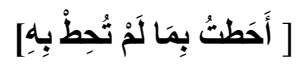

\footnotetext{
${ }^{(37)}$ Pole, Shadows, C 5, p. 381.

${ }^{(38)}$ See MuhannaNajm, The Hoophic Rules, p. 10.

${ }^{(39)}$ IbnKatheer, interpretation of the great Quran, c 6, p. 188.

(40) al-Bukhaari, Book of Hate, chapter on hatred of slander on slaves, H 2554, c. 3, p. 150.

${ }^{(41)}$ IbnAshour, Liberation and enlightenment, c 19, p. 254.

${ }^{(42)}$ IbnAshour, c 19, p. 254.

${ }^{(43)}$ Sa'eedHawa, The Basis of Interpretation, 7, p. 4008.

${ }^{(44)}$ Sa'eedHawa, The Basis of Interpretation, 7, p. 4010.
} 
"I have compassed (territory) which thou hast not compassed"

- The preacher must teach people what science he has, And not waiting for the point to be a great scholar.

- Giving the opportunity to the violator to present his proofs, and defend for himself, as you knew, Solaiman allowed the hoopoe to present his proofs when he said:

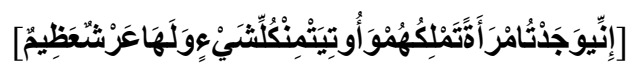

"I found (there) a woman ruling over them and provided with every requisite; and she has a magnificent throne".

- Ensure the validity of the news before its ratification, and confirmation before everything, and this is what Solomon did

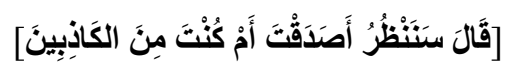

(Solomon) said: "Soon shall we see whether thou hast told the truth or lied.

\section{Chapter 4: Communication With Trees, Stones And Mountains}

\subsection{Part 1: Contact with Trees and Stones}

God Almighty created global customs do not change as clear signs, and miracles are impressive, God made them for prophets and messengers To erase the signs of shirk, Including the moral verses that suggest to people the truth of the prophets such as that God makes terror in the hearts of his enemies, Allah says in surah Al-Ahzab:

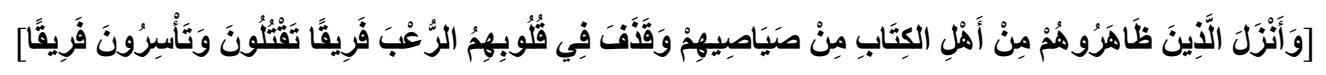

"And those of the People of the Book who aided them - Allah did take them down from their strongholds and cast terror into their hearts. (So that) some ye slew, and some ye made prisoners"

It is from the miracles: such as: splitting the moon, greeting of stone to the Prophet. When many people drink a small amount of water. When the non-believers will become so hungry because of their kufr. When many people eat a little amount of food. The miracle of Isra' "traveling" and Mi'raj "going to the heaven", when non-believers couldn't catch the Prophet. When tree trunk cried. When the camel complained, And when a sheep talking while being grilled. ${ }^{(45)}$

And other miracles that demonstrate the communication of the Prophet with many creatures including his connection with the trees and stones.

Therefore, human may contact with non-humans such as trees and stones, it's possible, Trees and stones may communicate with a man to encourage and support him to continue calling to Islam, There is many events in the life of the Prophet (peace and blessings of Allaah be upon him), Such as the gravel to praise in his hand and in the hands of some of his companions, trunk crying ,Having a very nice smell in every street he walks in, kneeling of trees and stones, This is mentioned by Imam alAsfahani - may God have mercy on him - in his book "Miracles of the Prophet Muhammad peace be upon him" He wrote a chapter about the prostration of trees and stones, Al-Asfahani wrote also a chapter about the praise of the stones in the hands of the Prophet.

In the hadeeth of Jabir ibnSamura, the Prophet said: "I know a certain stone in Mecca that was greeting me before I became a prophet. I assure you that I know it now"

In the book "Almostadrak" Ali bin AbuTalib said: We were with the Messenger of Allah peace be upon him in Mecca, when we were passing a tree or a stone, the tree or the stone greeted the Prophet peace be upon him. ${ }^{(46)}$

the trees and stones communicated with the Messenger of Guidance to suggest him, And this is a useful communication of stones and trees to the believer in support, which is also beneficial to the polytheists, so that their doubts will gone, it is a reason to enter the religion, And such communication

${ }^{(45)}$ Abu Mansour Al-Mataridi, Tawhid, p. 203.

${ }^{(46)}$ Al-Bayhaqi, Prophecies of Prophecy, 1, p. 
is a victory for the Messenger of Allah with soldiers weakened in ability, the enemies of God the Jews will fite believers until the stone continues with believers, so he has a proof of sincerity, Stones will say, O Muslim, this Jew behind me, kill him.

It's a punishment for destruction of those who do not believe , and do not expect, Imam al-Samaani (may Allaah have mercy on him) said: "In the story: that the people of Loot have deceived them, and the stone follows the shrapnel from them and destroyed them." Therefore, the diversity of torment is characterized by the diversity of defects,

This type of communication was a support and the believers, and torture and punishment of the criminals, and it is the reform of the insured society and its validity.

Man may begin to communicate with trees and stone, trees and will either continue.

So that the spiritual communication: sensing that this tree and stone created from the creation of God lives in a specific system, uniting God in the way God inspired them, they created from the creation of worshipers, praise their Lord night and day do not invent, The Prophet (peace and blessings of Allaah be upon him) said:" all creatures pray, a creature, or a creation, but you do not understand their praise. exceeding a saying for saying: if the gods with him as they claim if plotted to a throne, a way about the angels, they do not hasten the punishment, Forgiving delays in torment them to the period, In the hadeeth that 'Abd-Allaahibn' Umar said: "The Prophet (peace and blessings of Allaah be upon him) said: You testify that there is no god but Allah, and that Muhammad is his messenger etc. ${ }^{(47)}$

Mujahid said: Stones that were around the Kaaba were slaughtered and, they would change if they wanted to, and if they saw what, which is very in injustice, The imam al-Samaani said: The people of Al-Aikah were destroyed, and in the story: it caused them severe heat in their homes, and God forbade the wind For them, and stressed the heat on them, and were days, and then forced them perished all together". ${ }^{(4)}$

"The worship of graves (of the graves) and the worship of trees and stone are the trap of idolaters, and this has been done and what is greater than it in the latter of this nation". ${ }^{(49)}$ The result of this wrong and wrong communication with these creatures leads to that terrible conclusion in the world, and in the Hereafter hell reach it and the decision is bad, but it is better to communicate with it by sensing the greatness of this creation swimming with the kingdom, the greatness of God, And in the Hereafter they will follow the house.

\subsection{Part 2: Contact with Mountains}

The useful and the clear understanding, of the communication with the non-human that existed in the life of Solomon is a brilliant thing. The blessings that God has given us are many. God is Praise worthy.

And arrogance causes harm to the who did that, Allah says:

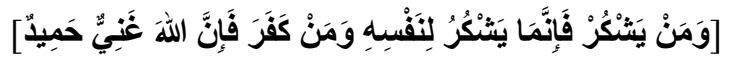

"And whoever is grateful is grateful for [the benefit of] himself. And whoever denies [His favor] then indeed, Allah is Free of need and Praiseworthy."

The denial of grace is a curse. "If they do not thank the grace of God, they will deserve the punishment" ${ }^{(50)}$

If a person is thankful, God gives him the increase of blessings, David peace be upon him was who won the honor of these blessings and he thanked God, Imam al-Tabari (may Allaah have mercy on him) said: "If we say to them, do the obedience of God, the family of David, thank for your kindness. on the blessing that He has, Among these blessings,

Communication with the mountains and with the birds, and how they praise Allah ,

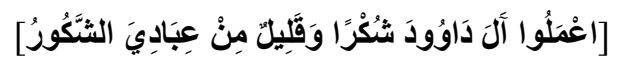

\footnotetext{
${ }^{(47)}$ Interpretation of Mujahid, p. 300.

${ }^{(48)}$ As-Samani, interpretation of the Koran, C 3, p. 148.

${ }^{(49)}$ Al-Samarqandi, Bahr al-Ulum, p. 139, c.

${ }^{(50)}$ Al-Samarqandi, Bahr al-Ulum, p. 139, c.
} 
"Work, O family of David, in gratitude." And few of my servants are grateful".

Imam al-Tabari (may Allaah have mercy on him) said: "we say to them, do the obedience of God, the family of David, thank Allah for the blessings that he has bestowed upon you, you've been chosen among all his creation"(51)

It was David praises, and the mountains and birds praise with him, in their own language "(52), this was not a one-time communication, But it was repeated between David "peace be upon him" and between the mountains and birds;

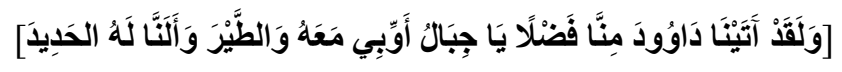

"And we certainly gave David from Us bounty. [We said], "O mountains, repeat [Our] praises with him, and the birds [as well]."

The meaning it is not that the mountains and the birds praise one time, but rather, that it repeat that. ${ }^{(53)}$

I say: this wonderful type of communication came to consolidate the concepts of faith, including that all the creatures in this universe to worship the God who worthy to worship alone, praising the God , and you know that all creatures share the praise with different languages they use In their praise.

\section{CONCLUSION}

All Praise be to Allah who helps us to do good deeds, I thank Allah and thank him for the facilitation in all things and at all times,

And peace and blessings be upon the best creature, the Prophet Muhammad, and upon his family, companions and followers,

I thank God who helped me to finish this research,

I ask God to make it acceptable in this world and in the Hereafter, and to make it as a work that causes the entry of Paradise and to make me to survive on the Day of Judgment.

So, now I will remind the readers what I'm able to conclude and recommend:

\subsection{Conclusions}

In this research, I found important results, notably:

- Communicating with the jinn are two types: A type in which the jinn communicates with humans through epilepsy, and the other type when a person communicates with the jinn without the epilepsy.

- Communication with jinn either useful or negative and harmful, for example about the positive communication useful: what happened between the Prophet peace be upon him with the jinn from the village of Naseebian.

And as an example of the negative communication: when a human being asks the jinn for something, which leads to magic and then harming people because of this type of communication.

- People's relationship with the jinn is limited, When a person wants to communicate with any person, they should communicate under the rules of Islam, so that the person does not fall into a sin or misguidance, you can use this communication with people for calling them to Islam.

- Not every case of epilepsy is caused by the jinn, because epilepsy is an ordinary disease which has its causes which known by doctors and it is not because of the jinn,

There is no problem in treating all kinds of diseases by Quran and Sunnah because; the Quran is a medicine in treatment of all diseases.

- The communication with stones sometimes is a useful communication because of encouraging and supporting believers,

${ }^{(51)}$ Al-Tabari, Al-Bayan Mosque, A 20, p. 368).

${ }^{(52)}$ Wahba al-Zuhaili, Explanation enlightening, c 17, p.

${ }^{(53)}$ Azzajjaj, Meanings of the Qur'an and its meaning, c. 4, p. 343. 
It is also beneficial to the non-believers, useful to the polytheists because it casts the doubt off, from their hearts, Then it is the reason for their conversion Islam, Sometimes this communication is a punishment for non-believers.

- Communication with trees and stones, is either a spiritual connection, or to get a witness or continuity makes a person apostate from Islam.

$>$ Spiritual communication, as the author claims is a matter of communication: It is when a Muslim feels that this tree or stone is praising by its way.

$>$ Communicating for a witness: when trees or stones testify for the truth of what the Muslim says.

$>$ The communication that causes the man to become a nun believer: It is when the human worships some creature.

- Communicating with the ant has had many benefits, briefly and in details, such as it is the cause of surviving for some creatures, it makes people remember the many blessings that God gave us; this is the purpose of useful communication with non-humans.

- One of the blessings that Allah gave to David, peace and blessings be upon him, that God commanded the mountains and the birds to praise Allah with David (peace be upon him).

- When the mountains and birds praise with David, this teaches us some lessons about the Islamic dogma, including: that all the creatures in this universe do praise and submit according to the way that fits this creature, See how this type of communication shows you that all creatures are praising Despite their different types, but they praise by the appropriate nature which created by God for each type of creatures.

- It is clear that there are educational lessons, doing good deeds in the story of Solomon peace be upon him with the hoopoe, when he communicated with him, and what appears from the workers from the hard working jinn, And when Solomon peace be upon him protected the right religion, And when the queen Balqis converted to Islam and worshiped Allah.

- The leader should take care of the workers and soldiers, He must take care of their affairs, And if he wasn't, so why we call him a manager or a leader?!, It is not correct to be satisfied just with the reports and the news that they bring, but a leader should watch by himself, Messenger of Allah peace be upon him said: "All of you are guardians and are responsible for your wards"

- It is the duties of managers or leaders to care about the situations of people or to order some of the workers to do that.

- From the story of the Hoopoe with Solomon -peace be upon him- that the hoopoe was very loyal to the state or kingdom, and that he is keen to protect the country and fighting enemies as much as possible. So, like that should be the model country.

- It is not a good moral to despise how less than you, in their level or position, because they may have some knowledge about something you do not know.

- Violators should be given the opportunity to present the proofs, to defend, Solomon (peace be upon him) allowed the hoopoe to prove that he was sincere.

\subsection{Recommendations}

And from the point of more benefits,- God willing - I will mention some of the recommendations that I felt they're important, while writing my research.

I recommend researchers and preachers, these tips:

- The researchers should try to extract precious and rare pearls from the best book and, it's the Holy Quran, it is a sea has no end.

- To promote researches that takes shows the right path, and the right, easy image of Islam, And to educate the Muslim preacher, who devotes for benefits, who can communicate with everyone, who has a positive impact while teaching people, who persuades non-Muslims that Islam is not the religion of terrorism, it's the religion of mercy and wisdom. 


\section{REFERENCES}

[1] IbnAshour: Mohamed Eltaher Ben Mohamed Ben Mohamed Eltaher Ben Ashour Tunisian (deceased: 1393 e), Liberation and Enlightenment - the liberation of the good meaning and enlightenment of the new mind of the interpretation of the glorious book.

[2] Ibn Fares: Ahmad bin Fares bin Zakaria al-Qazwini al-Razi, Dictionary of the Standards of Language, the investigation of Abdul Salam Mohammed Harun, first edition, 1399 to 1979, Dar al-Fikr.

[3] IbnKatheer: Abu al-FidaaIsma'ilibn 'Umar ibnQatheer al-Qurashi al-Basri and al-Damashqi (d. 774 AH), interpretation of the great quran, investigation: Muhammad Hussein Shams al-Din, ed. .

[4] IbnManzoor: Muhammad ibnMakram bin Ali, Abu al-Fadl, Gamal al-Din IbnManzoor al-Ansari alRuwaifi al-Afriyya, San al-Arab, first edition, 1414H, Dar Sader - Beirut.

[5] Abu Hanifa al-Nu'man bin Thabit bin Zooti bin Mah (deceased: 150 e), the greatest jurisprudence, first edition, 1419 e - 1999, Al Furqan Library - UAE.

[6] Abu Abdullah Al-Hakim Muhammad bin Abdullah bin Mohammed bin Hamdawiyah bin Naim bin alHakam al-Dhahbi al-Tahmani al-Nisaburi known as the son of the sale (deceased: 405 e), Al-Mustadrak on the right, the investigation: Mustafa Abdul Qader Atta, first edition,

[7] Abu Abdullah Muhammad bin Abdullah bin Isa bin Mohammed Al-Miri al-Abiri, known as IbnAbiZamanin al-Maliki (deceased: 399 e), interpretation of the Koran Aziz, investigation, Abu Abdullah Hussein bin Okasha - Egypt Cairo.

[8] Abu Muhammad Sahl bin Abdullah bin Younis bin Rafeeh al-Tastari (died: 283 AH), the interpretation of al-Tastari, collection of Abu Bakr Mohammed al-Baladi, investigation by Muhammad Basil Ayyoun alSud, first edition, Muhammad Ali Baydoun Publications.

[9] Abu Muhammad Ali bin Ahmed bin Said bin HazmAndalusianCyrptic virtual (deceased: 456 e), chapter in boredom and whims and bees, the library of the Khanji - Cairo.

[10] Ahmad ibn al-Husaynibn Ali ibn Musa al-Khasrojdi al-Kharasani, Abu Bakr al-Bayhaqi (d. 458 AH), evidence of prophecy and knowledge of the conditions of the shariah, first edition, 1405.

[11] Ahmed Glouche, The Biography of the Prophet and the Call in the Mecca Covenant, First Edition, 1424H2003M, The Foundation of the Message.

[12] Ahmed Glouche, Invitation of the Apostles, peace be upon them, first edition, 2002 - 2002.

[13] Al-Azhari: Muhammad bin Ahmed bin Al-Azhari Al-Harawi, Abu Mansur, language refinement, investigation by Mohamed AwadMarab, first edition, 2001, Revival of Arab Heritage - Beirut.

[14] Al-Alusi: Abu al-Ma'ali Mahmoud Shukri bin Abdullah bin Mohammed bin Abi Al-Tanna al-Alusi (d. $1342 \mathrm{AH}$ ), chapter of the discourse in explaining (issues of ignorance, in which the Messenger of Allah violated the people of the ignorance of Muhammad bin Abdul Wahab, may Allah have mercy on him) Ali bin Mustafa Makhlouf, first edition, 1422 e.

[15] Sa'idHawa, The Foundation of Interpretation, Dar es Salaam, Cairo, First Edition, 1985.

[16] Bukhari: Muhammad bin Ismail Abu Abdullah al-Bukhaari al-Jaafi, the mosque is the correct right hand of the things of the Messenger of Allah $\square$ and Sunnah and his days (SaheehBukhari), the investigation of Muhammad Zuhair bin Nasser Al-Nasser, first edition, $1422 \mathrm{e}$, the circle of salvation.

[17] Al-Razi: Zine El-Din Abu Abdullah Muhammad IbnAbiBakr Bin Abdul QaderHanafi Al-Razi, Mukhtar Al-Sahah, Investigation of Yousef Al-Sheikh Mohammed, First Edition, 1420 H-1999, Modern Library.

[18] Zubaidi: Mohammed bin Mohammed bin Abdul Razzaq al-Husseini, nicknamed al-Zubaidi, crown of the bride of the Dictionary Jawhar, Dar al-Hedaya.

[19] Al-Samarqandi: Abu al-Layth Nasr bin Mohammed bin Ahmed bin Ibrahim al-Samarqandi (died: 373 e), Bahr al-Ulum.

[20] The Samaritan: Abu al-Muzaffar, Mansoor bin Mohammed bin Abdul-Jabbar Ibn Ahmad Al-Marozi AsSamani al-TamimiHanafi and then Shafi'i (died: 489 e), interpretation of the Koran, investigation: Yasser bin Ibrahim and Ghaneim bin Abbas bin Ghneim, first edition, 1418 - 1997, , Al Riyadh, Saudi Arabia.

[21] Qutb Ibrahim Hussein Al-Sharabi (d. 1385 AH), in the shadow of the Koran, 17th edition - 1412, Dar AlShorouk - Beirut - Cairo.

[22] Shaarawi, thoughts, first edition, 1997, today's news outlets, c 17.

[23] Dr. Ali Abdullah bin Abdul Mohsen Al-Turki in cooperation with the Center for Research and Islamic Studies in Dar Hajr Dr. Abdel-Aziz Al-Tabari: Muhammad bin Jarir bin Yazid bin Katheer bin GhalibAmali, Abu Jaafar al-Tabari (died: 310 e) Sind HasanYamama Dar Hajar for Printing, Publishing, Distribution and Advertising, First Edition, 1422H - 2001 AD. 
[24] Abdul Rahman bin Hassan bin Mohammed bin Abdul Wahab bin Sulaiman Al-Tamimi, Tawhid and Kura Oyun Al-Muhaddin in the realization of the call of the Prophets and Messengers, investigation, Bashir Mohammed Oyoun, first edition, 1411 - 1990, Al Moayad Library, Taif, Saudi Arabia , Damascus, Syrian Arab Republic.

[25] Abdul Aziz Al-Salman, Al-Anwar Al-Mutairat for University Verses, First Edition, Dar Al-Shorouk Publishing.

[26] Ezz al-Din ibnAbd al-Salam: Abu Muhammad Izz al-Din 'Abd al-'Aziz ibn' Abd al-Salam ibnAbi alQasimibn al-Hasan al-Salami al-Damasqi, known as the Sultan of ulama (d. $660 \mathrm{AH})$, interpretation of the Qur'an , First Edition, 1996, Dar IbnHazm - Beirut.

[27] EssamSulaiman Al-Mousa, Introduction to Mass Communication, First Edition, 1998, Irfan Library.

[28] Omar Suleiman Abdullah Al-Ashqar, Islamic Creed in the Light of the Book and Sunnah - The World of the Jinn and the Devils, Special Edition in Egypt, the Maghreb and Yemen, Dar Al-Nafais Publishing and Distribution - Jordan.

[29] Mujahid: Abu al-HajjajMujahidibnJabr al-Taabi al-Makki al-Qurashi al-Makhzoumi (deceased: 104 e), investigation, interpretation of Mujahid, Dr. Muhammad Abdulsalam Abu-Nile, first edition, Modern Islamic Thought House, Egypt.

[30] Al-Hassan in the approximation of SaheehIbnHabban, the order of Prince Alaa al-Din Ali bin Bilban alFarsi (d. $739 \mathrm{AH}$ ) Achieved and came out of his conversations and commented on: ShoaibArnaout, first edition, the Foundation letter, Beirut.

[31] Muhammad bin Saleh bin Mohammed al-Othaimeen (died: 1421 e), useful comment on the Book of Tawheed, second edition, Dar Ibn al-Jawzi, Saudi Arabia.

[32] Muhammad bin Abdul Karim bin Ubaid Professor of Hadith and its Sciences Co-book and Sunnah University Umm Al-Qura University, graduation of the speeches attributed in the book of the great history of Bukhari, first edition, 1420 - 1999, Al-Rashed Library, Riyadh.

[33] Mohammed bin Abdullah al-Shibli Damascene Hanafi, Abu Abdullah, Badr al-Din IbnTaqi al-Din (died: 769 e), Akam Coral in the provisions of the elves, investigation: Ibrahim Mohamed Gamal, Library of the Koran - Egypt - Cairo.

[34] Mohammed bin Mohammed bin Mahmoud Abu Mansour Al-Matridi (deceased: 333 e), Tawheed, investigation, d. FathallahKhalif, Egyptian Universities House - Alexandria.

[35] Mohammed bin Mohammed Hassan Shurrab, the most famous monuments in the year and the biography, edition: First - 1411, Dar Al-Qalam, Dar Al-Shamiya - Damascus - Beirut, p. 192.

[36] Mahmoud Hassan Ismail, Principles of Communication Science and theories of Influence, First Edition, 2003, International Publishing and Distribution House.

[37] Musallamibn al-Hajjaj Abu al-Hasan al-Qusheiri al-Nisabouri (d. $261 \mathrm{AH}$ ). The correct and correct reference to the transfer of justice from justice to the Messenger of Allah.

[38] Fighter: Abulhasan fighter Bin Sulaiman bin Bashir Al-AzdiBalkhi (died: 150 e), the interpretation of the fighter investigator: Abdullah Mahmoud Shehata, first edition, 1423, House revival heritage - Beirut.

[39] MuhannaNaeemNajm - Member of the Committee of Scholars and Preachers of Palestine -, The Hoophic Rules of Tawheed and the Call to the Lord of the Wilderness, First Edition, 2010 .

[40] Wahba bin Mustapha al-Zuhaili, the enlightening interpretation of the doctrine, Shariah and the curriculum, second edition, contemporary think tank - Damascus.

[41] Yahya bin Salam bin AbiThalabah, who is loyal, from Tim Rabia, Basri and then African Kairouany (deceased: 200 e), interpretation Yahya Ben Salam, presentation and investigation: Dr. Hind Shalaby, first edition, Scientific Books House, Beirut - Lebanon.

Citation: Dr. Majed Rajab Al-Abid Sukkar. "The Prophets Communication with Non-Human Creatures in the Holy Qur'an and Its Influence on the Calling to Islam ". International Journal of Media, Journalism and Mass Communications (IJMJMC), vol 5, no. 1, 2019, pp. 1-15. doi:http://dx.doi.org/10.20431/2455-0043.050 1001

Copyright: (C) 2019 Authors. This is an open-access article distributed under the terms of the Creative Commons Attribution License, which permits unrestricted use, distribution, and reproduction in any medium, provided the original author and source are credited. 